\title{
Factors influencing consumers' purchase intention of green sportswear
}

\author{
Changhyun Nam* ${ }^{*}$, Huanjiao Dong and Young-A Lee
}

\author{
*Correspondence: \\ cnam@iastate.edu \\ Apparel, Merchandising, \\ and Design Program, \\ Department of Apparel, \\ Events, and Hospitality \\ Management, lowa State \\ University, 2302 Osborn \\ Drive, Ames, IA 50011-1078, \\ USA
}

\begin{abstract}
The purpose of this study was to examine consumers' purchase intention for green sportswear by investigating the effects of their expectation, perception, subjective norm, perceived behavior control, and attitude on purchasing green sportswear. The study further investigated differential influences towards purchase intention for green sportswear between non-green and green product users. A within-subjects research design was used to empirically test our conceptual model, which was expanded from the theory of planned behavior by adding two additional predictors (expectation and perception). An online survey was conducted with a nationwide convenience sample of U.S. consumers whose ages ranged from 18 to 74 years, and a total of 542 usable responses were obtained. The results of the overall model testing confirmed the significant effects of expectation, perception, subjective norm, and attitude on consumers' purchase intention for green sportswear. The findings from the comparative model testing indicated significant differences between non-green and green product users in terms of the effects of expectation and perceived behavior control on participants' green sportswear purchase intention. The outcomes of this study offer useful insights for developing effective strategies for consumers to generate more positive perception, expectation, and attitude towards purchasing green sportswear. This study also suggests potential ways for apparel retailers to develop effective marketing strategies for this sportswear segment to satisfy the values of potential customers.
\end{abstract}

Keywords: Green sportswear, Expectation, Perception, Purchase intention, Sustainability

\section{Introduction}

The sportswear industry has dramatically integrated into the apparel industry as fitness apparel, in particular, has become the most recent casual "uniform," contributing to the booming trend of "athleisure" (Pasquarelli 2014). The sportswear industry currently encompasses functional or performance clothing, sports-related attire, and fitness clothing (Mintel 2014) and its global market is expected to climb from $\$ 97$ billion in 2015 to $\$ 178$ billion in 2019 (Sherman 2014). In recent years, individuals have become to wear sportswear, interchangeably used as active wear, not only for engaging in sports, but also for everyday occasions (Lockwood 2012). This upsurge has attracted a number of new entrants such as casual-end retailers, creating competition for the already crowded sportswear market. 
The apparel industry continues to remain as one of the greatest polluters and the second largest consumer of water usage in the world (Sahni 2016). This industry consisting of fibers to production to the end consumers brings about serious social, economic, and environmental concerns, because of excessive uses of natural resources, chemical usage to make fabrics, and trends in fast fashion that promote consumers' compulsive purchasing behavior. Environmentally sustainable or "green" purchasing decisions in everyday consumer behavior, therefore, offer a chance to reduce negative environmental impacts by substituting higher-impact products (e.g., air fresheners, cosmetics, plastic bags) with products that are more eco-friendly. As consumers become more aware of consumption-related environmental problems, they simultaneously grow more cautions when purchasing products and eventually seek to purchase eco-friendly products for the betterment of current and future generations (Kilbourne and Pickett 2008; Laroche et al. 2001). Consistent with these phenomena, in the apparel industry, consumers' awareness and demands for green apparel have gradually increased.

Recently, more apparel companies, including sportswear companies, have joined as the members of the sustainable apparel coalition (SAC), a nonprofit trade organization founded by a group of leading apparel retailers and brands (e.g., Patagonia, Walmart, GAP, Levi's, Nike), to reduce the environmental impact of products for the betterment of people and the planet (Kaye 2011; Sustainable Apparel Coalition 2016). SAC members collaborate together to develop a variety of sustainable (or green) products, programs, and campaigns for consumers in our society. Nowadays, sustainability practices have become essential to maintain companies' long-term success and maintain their loyal customers. The growing popularity of sustainability around the globe increases the pressure on apparel and footwear companies to heavily consider developing sustainable apparel and its related products.

For other industries, in an attempt to determine means to identify and retain potential customers, researchers have examined the perceived attractiveness of green products' characteristics such as hybrid cars and green electronic products (e.g., PCs, monitors, printers) (Hast et al. 2015; Hur et al. 2015). Some studies also examined the relationships among consumers' perception, expectation, and purchasing behaviors for green products (Cowan and Kinley 2014; Diddi and Niehm 2016; Han and Chung 2014; Tseng and Hung 2013). However, limited research exists investigating how consumers perceive green sportswear, in particular, and what consumers expect from this specific green sportswear. Although the increasing numbers of sportswear companies have placed the heavy emphasis on incorporating sustainability into their product design and development practices and joined the SAC to measure their sustainability performance (e.g., environmental, social, labor impacts of making and selling their products and services), limited attention has been given to understanding the relationships of perception and expectation of potential green sportswear customers with their purchase intention.

The purpose of this study was to examine green sportswear purchase intention by investigating the effects of their expectation, perception, subjective norm, perceived behavior control, and attitude on purchasing green sportswear. In this study, green sportswear was defined as a specific product category made of natural and (or) recycling materials that use alternative fabrics or fibers (e.g., organic cotton, plastic bottle) with less pollution and less waste to preserve our nature. The two specific research 
objectives were to: (1) identify important predictors that influence U.S. consumers' purchase intention for green sportswear and (2) further investigate differential influences towards purchase intention for green sportswear between non-green and green product users. Notwithstanding the important contributions of past studies, there remains a lack of understanding of the barriers to non-green product users. Also, in spite of dynamic changes in the apparel industry in general, increased sales of sportswear, and increased emphases on environmental issues, little research has explored the ways to guide apparel designers, manufacturers, and retailers in understanding consumers' purchase behaviors regarding green sportswear more holistically. Therefore, we aimed this study to contribute to fill these gaps by explicitly examining the difference between non-green and green product users in terms of their purchase intention for green sportswear.

\section{Literature review}

This study used a modified theoretical framework integrating consumers' expectation and perception (Parasuraman et al. 1985; Tseng and Hung 2013) with the concepts within the theory of planned behavior that associates the psychological processes, how an individual's subjective norm, perceived behavioral control, and attitude lead to one's behavioral intention (Ajzen 1991). This modified framework was used to examine consumers' attitude towards green sportswear and social norm that describes the social pressure a person receives while performing certain behaviors. This information was used to infer consumers' perception and expectation to accomplish their purchasing behavior.

\section{Expectation and perception}

The perceived service quality concept by Parasuraman et al. (1985) emphasizes the degree and direction of distinction between consumers' expectation and their perception. Generally, expectation and perception significantly influence consumers' satisfaction of a certain product (Parasuraman et al. 1985; Tsiotsou 2006). Consumers determine whether a product's performance meets their expectation based on their satisfaction level regarding the current requirements for a given product (Oliver 1981). Perceived product quality associated with consumers' expectation and perception has a direct positive influence on consumers' purchase intention (Boulding et al. 1993; Tsiotsou 2006).

Tseng and Hung (2013) classified 11 sustainable attributes into three dimensions (tangibility, assurance, reliability) to measure differences between consumers' expectation and perception associated with green products. Their results showed that when consumers' expectation was significantly higher than the perceived quality of the products, many were not willing to purchase green products. This finding can be interpreted as consumers intend to purchase green products if their expectation is equivalent to their perception.

Consumers may acquire their expectation through word-of-mouth, experience, and social media (Anderson and Fornell 2000). Consumers' expectation can be predicted and observed with regard to beliefs and the reliability regarding products or services (Lee et al. 2014). For example, consumers who are dissatisfied with apparel products hold fewer expectation when exposed to negative word-of-mouth as well as exhibiting less repurchasing behavior with the product (Richins 1983). Also, consumers increasingly 
expect retail brands to behave in line with ethical fashion practices, because their expectation has formed a reference point for their evaluation of socially responsible business practices and eco-products to develop favorable or unfavorable attitude towards retail brands (Creyer and Ross 1997).

Consumers' perception of eco-friendly brands provides positive influences to their purchasing behavior (Lee et al. 2012). When purchasing products, consumers' positive or negative experiences toward the products could be accumulated (Sproles 1979), which may lead to change their purchasing behavior (Smith and Swinyard 1983). Therefore, actual product trials, here experience, can have greater effect on consumers' attitude than the product advertising (Lee et al. 2012). Consumers' perception has also been shown to directly influence their purchase intention for organic or green products, because of perceiving the products to be more environmentally friendly, safe, and good for their health (Lai and Cheng 2016). As consumers believe that apparel made of organic cotton is beneficial to the environment, they tend to have favorable attitudes towards purchasing such apparel (Han and Chung 2014). From these past study results, we may conclude, if consumers have the experience of purchasing green sportswear, their purchase intention can be affected by their perception toward the green sportswear. In light of previous research, the following hypotheses were proposed for this study:

Hypothesis 1 Expectation positively influences (a) consumers' attitude towards green sportswear and (b) consumers' purchase intention for green sportswear.

Hypothesis 2 Perception positively influences (a) consumers' attitude towards green sportswear and (b) consumers' purchase intention for green sportswear.

\section{Subjective norm}

A subjective norm, the perceived social force for carrying out a particular behavior, is a function of referent's beliefs, constituting social pressure placed upon consumers by their families, relatives, or close friends and is considered before an individual performs a behavior (Ajzen 1991). This norm reveals the extent to which an individual feels morally responsible for others by buying green products and how important positive social image is to consumers (Barber et al. 2014). Therefore, when purchasing products, a subjective norm plays a functional role in reflecting a consumer's perception of his or her close relationships, such as whether their referents think he or she should purchase a product and his or her motivations to conform to the referents (Noble et al. 2009). When their referents have strong negative feelings about a product, consumers are more likely to adjust their purchase intention; likewise, a customer's purchase intention would be elevated if others more positively reference the same product (Kotler and Keller 2006).

Subjective norm has direct, significant relationships with attitude, perceived behavioral control, and purchase intention of artificial apparel (Kim and Karpova 2010). Subjective norms not only play an important role in an individual's purchasing decision, but also are positively associated with a consumer's attitude towards certain types of behavior (Han and Chung 2014; Paul et al. 2016). Subjective norms are also important predictors for environmental-related behaviors (Ko 2012; Zheng and Chi 2015), second-hand 
clothing consumption (Xu et al. 2014), and green product consumption (Paul et al. 2016). Therefore, when purchasing green sportswear, consumers may be influenced by information from environmental awareness groups who make claims about the positive effects of purchasing eco-friendly apparel. Based on previous findings, the following hypothesis was proposed for this study:

Hypothesis 3 Subjective norm directly influences (a) consumers' attitude; (b) perceived behavioral control; and (c) purchase intention for green sportswear.

\section{Perceived behavioral control}

Perceived behavioral control (PBC) reflects people's perception of how easy or difficult it is to perform a behavior (Ajzen 2002). It reflects perception regarding access to resources and opportunities needed to accomplish behavior, including access to money, time, and other resources, and the focal person's self-confidence in the ability to carry out the behavior (Ajzen 1991; Taylor and Todd 1995). Consumers' PBC towards purchasing organic products positively influences their purchase intention (Kim and Chung 2011). If consumers consider the price for eco-friendly apparel is too high, they tend to purchase other traditional apparel instead of this sustainable apparel (Joergens 2006).

Although consumers have a positive attitude with green products, they might not always purchase the products influenced by PBC (e.g., price) (Mandese 1991). PBC is not only a powerful factor influencing to attitude and behavior change, but also is related to salient beliefs that have been regarded as important resources for decision-making (Armitage and Talibudeen 2010; Ajzen and Madden 1986). Roberts (1996) also argues that $\mathrm{PBC}$ can positively influence consumers' attitude and purchase intention. When a consumer considers that significant others may not agree to purchase a product, he or she may experience psychological obstacles to performing this behavior, negatively affecting to one's PBC (Kim and Karpova 2010). Therefore, this study proposes that the higher the PBC, the higher the purchase intention for green sportswear. Based on the previous findings, we proposed the following hypothesis:

Hypothesis 4 Perceived behavioral control directly influences (a) consumer's attitude and (b) purchase intention for green sportswear.

\section{Attitude and purchase intention}

Attitude, which contributes to beliefs, plays a prominent role in decision-making. Ultimately the decision to perform a behavior is relative to an individual's attitude and his or her overall evaluation of a specific behavior (Tonglet et al. 2004). Behavioral intention refers to an individual's subjective possibility of engaging in a behavior, which can be influenced by attitudes towards performing the behavior (Ajzen and Fishbein 1980). There is a positive correlation between consumers' attitude and their willingness to pay more for sustainable products (Laroche et al. 2001). Consumers tend to engage in a behavior when they have more favorable attitude towards and intention for completing that behavior (Ajzen 1991). A strong positive relationship was identified between 
attitude towards and purchase intention for eco-friendly apparel (Chen and Chai 2010; Cowan and Kinley 2014; Zheng and Chi 2015). The intention of consumers to purchase green products is determined by a positive attitude towards green products (Vazifehdoust et al. 2013).

Paul et al. (2016) found that the direct and indirect influences of environmental concern through attitude on green behavioral intention, which can be concluded as attitude plays a vital role as a mediator between purchase intention and other variables. Johe and Bhullar (2016) also found that consumers' attitude indirectly mediated the effect of organic identity on consumers' purchase intention. Consumers who have more environmentally conscious attitude are more likely to purchase eco-friendly apparel (Umberson 2008). Based on the previous findings, we proposed the following hypothesis:

Hypothesis 5 Attitude towards purchasing green sportswear positively relates to a consumer's purchase intention for green sportswear.

Summary of the hypothetical relationships among the variables are shown in Fig. 1.

\section{Methods}

A quantitative research methodology was employed using an online survey. University's Internal Review Board (IRB) approval was obtained before the data collection.

\section{Sample and data collection}

Using a convenience sampling method, diverse U.S. male and female consumers aged 18 years old and over were recruited via Amazon Mechanical Turk (MTurk), as empirical

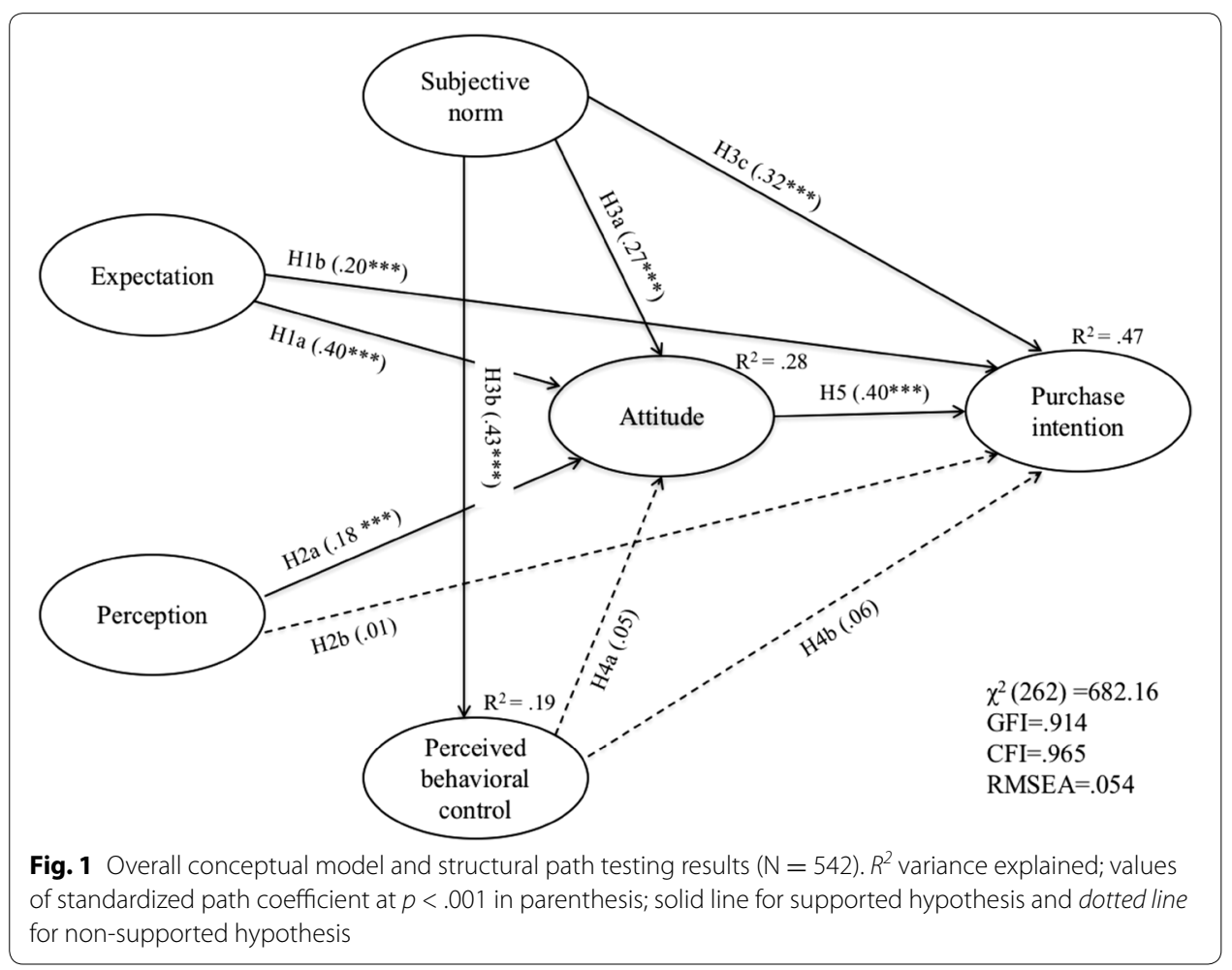


studies have indicated that MTurk data are as reliable as the traditionally collected data (Goodman et al. 2013). Participants took approximately 15-20 min to complete a webbased questionnaire and received 90 cents as their compensation.

To control diverse spectrum of participants' understanding for green sportswear, at the beginning of online survey, we provided the definition of green sportswear used in this study: a specific product category made of natural and (or) recycling materials that use alternative fabrics or fibers (e.g., organic cotton, plastic bottle) with less pollution and less waste to preserve our nature. Then we guided them to respond the survey questions based on this defined term. Participants were categorized into two groups later for data analyses: Group 1 (G1) non-green product users who had never purchased any green products and Group 2 (G2) green product users who had experience purchasing general green products (e.g., green kitchen utensils, eco-friendly cosmetic, organic food, green sportswear).

\section{Survey instruments}

This study employed multiple-item measurements that have been validated and determined as reliable. All six constructs (expectation, perception, subjective norm, perceived behavioral control, attitude, and purchase intention) were adapted and modified from previous research (see Table 1) and measured on a 7-point Likert-type scale ( 1 = strongly disagree to $7=$ strongly agree). Tseng and Hung's (2013) 11 items of sustainability attributes were adapted and modified to measure both expectation and perception variables. All measurement items were same for both variables, except the verb tense (e.g., will have vs. has). For each measurement item, the original phrase in Tseng and Hung's (2013) study, "the green information product," was replaced to "green sportswear" for this study. For example, one of original items to measure perception, "The green information product has eco-labels" was modified as "The green sportswear has eco-labels." One of original items to measure expectation, "The green information product will have eco-labels," was modified to "The green sportswear will have eco-labels." All of the rest items for these two variables, perception and expectation, were modified using the same procedure mentioned above.

Other measurement items were modified from 3-items of subjective norm (Fitzmaurice 2005), 3-items of perceived behavioral control (Chang 1998), 7-items of attitude (Chang 1998; Fitzmaurice 2005; Madden et al. 1992), and 3-items of purchase intention (Madden et al. 1992). The survey also included a demographic information section (e.g., green product purchase experience, age, gender, ethnicity, education level).

Each expectation and perception measure consisted of 11 sustainability attributeitems within three sub-dimensions: (1) tangibility (4 items; visual or explicit information to measure green products consisting of appearance, eco-labels, labeling of product ingredients, and user-friendliness); (2) assurance (4 items; belief, trust, and confidence in green products including environmental impact of materials, recyclability ratio, energy conservation rates, and recycling packing materials); and (3) reliability (3 items; green products' promised ability to perform with respect to functional performance, conformance, and durability) (Tseng and Hung 2013). 
Table 1 Final measurement model testing results

\begin{tabular}{|c|c|c|c|}
\hline Constructs and measurement items ${ }^{a}$ & $\begin{array}{l}\text { Standardized } \\
\text { factor loading }\end{array}$ & Cronbach's $a$ & $\mathrm{ITC}^{\mathbf{b}}$ \\
\hline Expectation of green sportswear (5 items) & & .909 & \\
\hline The green sportswear will have a nice appearance & .754 & & .718 \\
\hline The operation of the green sportswear will be user friendly & .760 & & .723 \\
\hline The green sportswear will have good functional performance & .883 & & .829 \\
\hline $\begin{array}{l}\text { The design and operating characteristics of green sportswear will meet } \\
\text { the established standards }\end{array}$ & .823 & & .777 \\
\hline The green sportswear will have good durability & .871 & & .818 \\
\hline Perception of green sportswear ( 6 items) & & .903 & \\
\hline The green sportswear has labeled the product ingredients clearly & .731 & & .688 \\
\hline The green sportswear has eco-label & .764 & & .721 \\
\hline The green sportswear is made from no polluted materials & .822 & & .772 \\
\hline The green sportswear has high recyclability ratio & .831 & & .780 \\
\hline The green sportswear has high energy conservation rate & .758 & & .715 \\
\hline The green sportswear has used recycling packing materials & .778 & & .733 \\
\hline Subjective norm (3 items) & & .835 & \\
\hline $\begin{array}{l}\text { Close friends and family think it is a good idea for me to buy green } \\
\text { sportswear }\end{array}$ & .793 & & .704 \\
\hline The people who I listen to could influence me to buy green sportswear & .686 & & .633 \\
\hline Important people in my life want me to buy green sportswear & .910 & & .764 \\
\hline Perceived behavioral control (2 items) & & .896 & \\
\hline For me, to buy green sportswear is easy & .901 & & .812 \\
\hline If I want to, I could easily buy green sportswear & .901 & & .812 \\
\hline Attitude (7 items) & & .953 & \\
\hline Bad vs good & .850 & & .824 \\
\hline Foolish vs wise & .902 & & .874 \\
\hline Harmful vs beneficial & .826 & & .802 \\
\hline Unfavorable vs favorable & .867 & & .845 \\
\hline Unsatisfactory vs satisfaction & .865 & & .847 \\
\hline Not valuable vs valuable & .864 & & .856 \\
\hline Worthless vs worthwhile & .891 & & .870 \\
\hline Purchase intention (3 items) & & .964 & \\
\hline I intend to buy green sportswear in the future & .912 & & .896 \\
\hline I will try to buy green sportswear in the future & .972 & & .942 \\
\hline I will make an effort to buy green sportswear in the future & .962 & & .933 \\
\hline
\end{tabular}

\section{Data analysis procedures}

Structural equation modeling using AMOS version 23 was performed to test the hypothesized paths. Each measurement model was first validated by running a confirmatory factor analysis. Parameters were estimated using the maximum likelihood method. For model fit, we used the goodness of fit index (GFI), comparative fit index (CFI), and root mean square error of approximation (RMSEA). Sobel test was also performed for examining the degree of a mediation effect of attitude on other variables (Sobel 1986). For further in-depth analysis, SPSS version 23 was used to run an independent $t$ test for examining significant mean differences between the two consumer groups (nongreen and green product users) in 11 sustainability attribute-items of perception and expectation. 


\section{Results and discussion}

\section{Sample characteristics}

A total of 542 usable responses were obtained after removing a total of 89 incomplete responses. The participants' ages ranged from 18 to 74 years with a mean age of 33 . About 53\% were women and $47 \%$ were men. The majority was Caucasian/European American (75.3\%) followed by African American (8.4\%), Asian (6.7\%), and others (9.7\%). Most (90\%) had obtained a college degree. Among the 542 participants, 134 were nongreen product users $\left(\mathrm{N}_{\mathrm{G} 1}=134\right)$ and the rest $\left(\mathrm{N}_{\mathrm{G} 2}=408\right)$ were green product users including those who had used green sportswear.

\section{Measurement model testing results}

The fit indices of the measurement model indicated an acceptable fit: $\chi_{(257)}^{2}=438.414$, $p<.001$, GFI $=.941$, CFI $=.985$, RMSEA $=.036$ (Hair et al. 2009). As shown in Table 1 , standardized factor loadings ranged from .686 to .972 and Cronbach's $\alpha$ values were all higher than .70 (Hair et al. 2009), ranging from .835 to .964 . This was the result of removing several items performing below .50 for certain variables ( 6 expectation items, 5 perception items, and 1 perceived control behavior item). After removing those items, item-total correlations were all over .30 (Nunnally and Bernstein 1994). Convergent validity and internal consistency were also satisfied (Hair et al. 2009). Discriminant validity of each construct was tested using the average variance extracted (AVE) and ranged from .611 to .902. The AVE for each construct was higher than its correlations with any other construct at $p<.01$ (see Table 2$)$.

\section{Structural model and hypothesis testing results}

Structural equation modeling (SEM) analysis was first performed to test the research hypotheses $(\mathrm{H} 1-\mathrm{H} 5)$ in an overall conceptual framework with all study participants $(\mathrm{N}=542)$. The next step was to compare the two different groups $\left(\mathrm{N}_{\mathrm{G} 1}=134\right.$ and $\mathrm{N}_{\mathrm{G} 2}=408$ ) in the same framework with each hypothesis.

\section{Overall path model test results}

An acceptable model fit was achieved for the overall conceptual framework: $\chi_{(262)}^{2}=682.160, p<.001, \mathrm{GFI}=.914, \mathrm{CFI}=.965$, RMSEA $=.054$ (see Fig. 1 ). The H1 results demonstrated that expectation (a) had a positive influence on consumers' attitude

Table 2 Correlation coefficients among factors

\begin{tabular}{|c|c|c|c|c|c|c|c|c|}
\hline & Mean & $S D$ & Expectation & Perception & SN & PBC & Attitude & PI \\
\hline Expectation & 5.62 & 1.03 & - & & & & & \\
\hline Perception & 5.86 & .90 & $.510^{* *}$ & - & & & & \\
\hline SN & 4.12 & 1.29 & $.323^{* *}$ & $.244^{* *}$ & - & & & \\
\hline PBC & 4.37 & 1.56 & $.244^{* *}$ & $.210^{* *}$ & $.397^{* *}$ & - & & \\
\hline Attitude & 6.02 & 1.07 & $.515^{* *}$ & $.397^{* *}$ & $.395^{* *}$ & $.230 * *$ & - & \\
\hline $\mathrm{Pl}$ & 4.89 & 1.44 & $.492^{* *}$ & $.333^{* *}$ & $.520^{* *}$ & $.309^{* *}$ & $.621^{* *}$ & - \\
\hline AVE & & & .672 & .611 & .643 & .825 & .751 & .902 \\
\hline
\end{tabular}

$S N$ subjective norm, $P B C$ perceived behavioral control, $P$ I purchase intention, $S D$ standard deviation, AVE average variance extracted

** $p<.01$ 
$(\gamma=.404, t=9.273, p<.001)$ and (b) directly influenced consumers' purchase intention towards green sportswear $(\gamma=.200, t=5.059, p<.001)$. Our study indicates that expectation is an important factor for influencing consumers' attitude towards and purchase intention for green sportswear, which supports previous findings by Lee et al. (2014).

$\mathrm{H} 2 \mathrm{a}$ was supported, indicating that perception had positive influences on consumers' attitude $(\gamma=.184, t=4.380, p<.001)$, which is consistent with previous studies regarding apparel made of organic cotton (Han and Chung 2014). However, H2b was not supported; perception did not directly influence consumers' purchase intention for green sportswear, which is inconsistent with a previous study on consumers' previous experiences with green products (Kim and Chung 2011). This non-supported result may mean that consumers can form different perception toward different product categories; for instance, consumers' perception may differ between green sportswear and other green products.

All H3s were supported, which predict that subjective norm (a) had a positive influence on consumer attitude $(\gamma=.432, t=5.682, p<.001)$; (b) had a significant effect on perceived behavioral control $(\gamma=.271, t=7.877, p<.001)$; and (c) directly influenced purchase intention $(\gamma=.318, t=7.334, p<.001)$. This confirms previous research findings on the positive influence of subjective norm on eco-friendly purchase behavior, attitude, and perceived behavior control (Cowan and Kinley 2014; Liobikiene et al. 2016; Paul et al. 2016). If consumers feel more pressure from significant others to purchase green apparel, they may become more engaged in purchasing green apparel products (Ko 2012). Therefore, in this study peer pressure from families or close friends could have influenced consumers' purchase intention for green sportswear.

$\mathrm{H} 4 \mathrm{~s}$, on predicting perceived behavioral control (PBC) significantly influencing (a) consumer's attitude and (b) purchase intention for green sportswear, were not supported. The findings are contradicted by Ajzen (2002) and previous studies, where PBC positively influences consumers' attitude and purchase intention (Gopi and Ramayah 2007; Kang et al. 2013; Kim and Chung 2011). It is possible that when purchasing green sportswear, particularly, consumers care not only about time, money, and capabilities, but also other factors, which may more heavily influence their attitude and purchase intention.

$\mathrm{H} 5$, regarding the positive influence of consumers' attitude on their purchase intention for green sportswear, was supported $(\gamma=.399, t=9.092, p<.001)$. Attitude partially mediated the effect of expectation and subjective norm on purchase intention. Attitude also fully mediated the effect of perception on purchase intention. However, attitude did not significantly carry the influence of $\mathrm{PBC}$ to purchase intention. This result presents the significant role of consumers' attitude as a mediator in consumer purchase intention for green sportswear, which is consistent with previous findings stating the significant correlation between attitude and green product purchase intention (Rahbar and Wahid 2011; Chen and Chai 2010). Kang et al. (2013) argued that if consumers have enough information and shopping experience with sustainable textiles and apparel, they would develop positive perception of and attitude towards consumption, which would lead them to have stronger intention to purchase the products. Findings from $\mathrm{H} 5$ provide some insights for apparel retailers. Retailers need to provide more information of green products and consumer experience campaigns of these products to consumers, which may further enhance consumer attitude towards purchasing green sportswear. 


\section{Comparative model test results}

Comparative model testing was conducted to investigate how different factors perform differently between non-green and green product users' purchase intention for green sportswear. The fit indices demonstrated acceptable fit: $\chi_{(542)}^{2}=1076.912, p=.000$, GFI $=.876, \mathrm{CFI}=.954$, RMSEA $=.044$. As shown in Table 3, the hypotheses, in general, were more statistically supported by the green product users (G2) than non-green product users (G1). The findings indicated significant differences between G1 and G2 in terms of the direct effects of expectation and perceived behavior control on participants' green sportswear purchase intention. It is because green product users had a positive experience of green products. Also, perception directly influenced attitude toward green sportswear for G2; but did not supported for G1.

H1a suggested the significant influence of expectation on consumers' attitude towards green sportswear for both G1 $(\gamma=.616, t=6.818, p<.001)$ and G2 $(\gamma=.356, t=7.212$, $\mathrm{p}<.001)$. For H1b, G2's expectation positively affected their purchase intention for green sportswear $(\gamma=.220, t=4.946, p<.001)$ while G1's expectation did not directly affect their purchase intention for green sportswear $(\gamma=.060, t=.653, p=.514)$. Expectation for green sportswear, therefore, could be positively raised with trust and belief regarding less negative environmental impact between both G1 and G2. However, it is possible that G1 lacked knowledge and information regarding green sportswear.

For H2 s, G1's perception did not significantly impact either attitude $(\gamma=-.037$, $t=-.507, p=.612)$ or purchase intention for green sportswear $(\gamma=.003, t=.211$, $p=.832)$. On the other hand, G2's perception positively influenced attitude $(\gamma=.175$, $t=3.591, p<.001)$, but not purchase intention $(\gamma=.030, t=.709, p=.478)$. The results

Table 3 Hypothesis test results and mediation results between two different consumer groups

\begin{tabular}{|c|c|c|c|c|}
\hline \multirow[t]{3}{*}{ Hypothesis and moderation } & \multicolumn{4}{|l|}{ Result } \\
\hline & \multicolumn{2}{|l|}{$\mathrm{G} 1(\mathrm{~N}=134)$} & \multicolumn{2}{|l|}{$\mathrm{G} 2(\mathrm{~N}=408)$} \\
\hline & $P$ value & $Z$ value & $P$ value & $Z$ value \\
\hline H1a: expectation $\rightarrow$ attitude & Supported ${ }^{* * *}$ & & Supported ${ }^{* * *}$ & \\
\hline $\mathrm{H} 1 \mathrm{~b}$ : expectation $\rightarrow \mathrm{PI}$ & Not supported & & Supported ${ }^{* * *}$ & \\
\hline M1: expectation $\rightarrow$ attitude $\rightarrow$ PI & Fully supported & .001 & Partially supported & .001 \\
\hline H2a: perception $\rightarrow$ attitude & Not supported & & Supported ${ }^{* * *}$ & \\
\hline H2b: perception $\rightarrow$ PI & Not supported & & Not supported & \\
\hline M2: perception $\rightarrow$ attitude $\rightarrow$ PI & Not supported & .614 & Fully supported & .001 \\
\hline H3a: $\mathrm{SN} \rightarrow$ attitude & Supported ${ }^{* * *}$ & & Supported ${ }^{* * *}$ & \\
\hline $\mathrm{H} 3 \mathrm{~b}: \mathrm{SN} \rightarrow \mathrm{PBC}$ & Supported ${ }^{* * *}$ & & Supported ${ }^{* * *}$ & \\
\hline $\mathrm{H} 3 \mathrm{c}: \mathrm{SN} \rightarrow \mathrm{Pl}$ & Supported ${ }^{* * *}$ & & Supported ${ }^{* * *}$ & \\
\hline $\mathrm{M} 3: \mathrm{SN} \rightarrow$ attitude $\rightarrow \mathrm{PI}$ & Partially supported & .011 & Partially supported & .001 \\
\hline H4a: PBC $\rightarrow$ attitude & Not supported & & Not supported & \\
\hline $\mathrm{H} 4 \mathrm{~b}: \mathrm{PBC} \rightarrow \mathrm{Pl}$ & Not supported & & Supported* & \\
\hline M4: PBC $\rightarrow$ attitude $\rightarrow$ PI & Not supported & .771 & Not supported & .083 \\
\hline H5: attitude $\rightarrow$ PI & Supported ${ }^{* * *}$ & & Supported ${ }^{* * *}$ & \\
\hline
\end{tabular}

G1 non-green product users, $G 2$ green product uses, $H$ hypothesis, $M$ moderation, $S N$ subjective norm, $P B C$ perceived behavioral control, $P /$ purchase intention

${ }^{*} p<.05$

*** $p<.001$ 
show that there is a difference in the attitude of G1 and G2 regarding their perception of green sportswear quality.

All H3s were supported; subjective norm for both G1 and G2 (a) had a positive influence on consumers' attitude $(\gamma=.253, t=2.903, p<.01 ; \gamma=.264, t=4.836, p<.001)$; (b) had a significant effect on PBC $(\gamma=.436, t=4.205, p<.001 ; \gamma=.422, t=6.625$, $p<.001)$; and (c) directly influenced purchase intention $(\gamma=.294, t=3.432, p<.001$; $\gamma=.328, t=6.599, p<.001)$. This is consistent with the previous finding suggesting that subjective norm is an important predictor of green purchasing behaviors (Moser 2015). One of the motivations for consumers' green consumption was to comply with other referents, and younger people are more easily affected by what others think about an issue than older populations (Coleman et al. 2011).

H4 s were partially supported; for G1, their PBC did not have any effect on attitude $(\gamma=-.025, t=-.295, p=.768)$ or purchase intention for green sportswear $(\gamma=-.005$, $t=-.063, p=.950$ ). For G2, furthermore, PBC did not have any significant positive influence on their attitude $(\gamma=.082, t=1.751, p=.080)$; however, had a direct positive effect on their purchase intention for green sportswear $(\gamma=.086, t=2.119, p<.05)$. In accordance with previous studies, PBC proved to be an antecedent of behavioral intention for ethical fashion consumption (Joergens 2006). In this study, PBC performed differently on purchase intention for the two consumer groups. According to Ajzen (1991), the effects of subjective norm, attitude, and $\mathrm{PBC}$ on purchase intention may be different across various consumer groups and their situations. Green products are often perceived to be more expensive than traditional products. It is obvious that the price of a product is an important factor in the decision-making process, especially for those unconcerned consumers who are not willing to pay higher prices for green products or for consumers with limited resources (Moser 2015). Therefore, for G2, the results of the positive effect of $\mathrm{PBC}$ on purchase intention indicate that they will form favorable attitude towards green sportswear consumption when they have the available resources.

The results of $\mathrm{H} 5$ presented the significant effect of attitude on purchase intention for both G1 $(\gamma=.360, t=5.271, p<.001)$ and G2 $(\gamma=.541, t=7.368, p<.001)$. The findings of this study supported the findings from previous studies, confirming the strong relationships of attitude with future intention in terms of eco-friendly apparel consumption (Cowan and Kinley 2014). Attitude has been confirmed as an important factor for determining purchase intention among various studies on green apparel (Kim and Karpova 2010; Ko 2012), and played a role of mediator in organic consumerism (Johe and Bhullar 2016).

Sobel test was also performed for examining the degree of a mediation effect of attitude on other variables. The results presented that attitude toward green sportswear had the higher degree of mediation effect for G2 than G1. Relationships between perception and purchase intention, for example, were not mediated by attitude for G1 (see Table 3).

\section{Further analysis results}

The results of hypothesis testing identified some important predictors of U.S. consumers' purchase intention for green sportswear; however, two constructs (perception and expectation) generated different results by two different consumer groups (nongreen product users vs. green product users). Therefore, an additional analysis was 
administered to explore the reasoning behind these differences. Roles of 11 sustainability attribute-items of expectation and perception were also examined to understand the effect of key factors on consumers' purchase intention for green sportswear between the two different consumer groups. An independent $t$-test was performed to examine whether there was any significant mean difference (MD) between the two consumer groups in 11 sustainability attribute-items under three sub-dimensions of perception and expectation (see Table 4).

As shown in Table 4, most attribute-items of all three sub-dimensions of both perception and expectation were not statistically significant between the two groups. However, green product users had higher mean scores of attribute-items in all three sub-dimensions and every attribute of both expectation and perception as compared to those of non-green product users in general. For expectation, the reliability sub-dimension items had the largest MDs between the two groups, whereas for perception, the assurance sub-dimension items included the largest MDs between the two groups. Green product users not only held higher expectation of green sportswear's ability to perform well, but also more deeply considered the trustworthiness of its environmental claims, compared to non-green product users. The lowest MDs between the two groups were tied with the conformance item $(\mathrm{MD}=-.08)$ under reliability and the appearance item $(\mathrm{MD}=-.09)$ under tangibility. Although the results show the MDs between the two groups, the energy conservation item under assurance was the only statistically significant one

Table 4 Mean differences in perceptions and expectations between green and non-green product users

\begin{tabular}{|c|c|c|c|c|c|c|}
\hline \multirow{2}{*}{$\begin{array}{l}\text { Sub-dimen- } \\
\text { sions/attrib- } \\
\text { ute items }\end{array}$} & \multicolumn{3}{|l|}{ Expectation } & \multicolumn{3}{|l|}{ Perception } \\
\hline & $\begin{array}{l}\mathrm{G} 1 \text { mean }(\mathrm{SD}) \\
\left(\mathrm{N}_{\mathrm{G} 1}=134\right)\end{array}$ & $\begin{array}{l}\mathrm{G} 2 \text { mean }(\mathrm{SD}) \\
\left(\mathrm{N}_{\mathrm{G} 2}=408\right)\end{array}$ & $\begin{array}{l}\text { Mean differ- } \\
\text { ence }\end{array}$ & $\begin{array}{l}\mathrm{G} 1 \text { mean }(\mathrm{SD}) \\
\left(\mathrm{N}_{\mathrm{G} 1}=134\right)\end{array}$ & $\begin{array}{l}\mathrm{G} 2 \text { mean }(\mathrm{SD}) \\
\left(\mathrm{N}_{\mathrm{G} 2}=408\right)\end{array}$ & $\begin{array}{l}\text { Mean dif- } \\
\text { ference }\end{array}$ \\
\hline Tangibility & $5.64(.91)$ & $5.76(.84)$ & -.12 & $5.64(.91)$ & $5.76(.84)$ & -.12 \\
\hline $\begin{array}{l}\text { Labeling of } \\
\text { product }\end{array}$ & $5.70(1.12)$ & $5.83(1.08)$ & -.13 & $5.68(1.18)$ & $5.86(1.06)$ & -.18 \\
\hline Eco-label & $5.95(.98)$ & $5.99(.92)$ & -.04 & $5.80(1.14)$ & $5.99(.96)$ & -.19 \\
\hline Appearance & $5.31(1.22)$ & $5.46(1.25)$ & -.15 & $5.29(1.21)$ & $5.38(1.31)$ & -.09 \\
\hline $\begin{array}{l}\text { User friendli- } \\
\text { ness }\end{array}$ & $5.61(1.03)$ & $5.76(1.05)$ & -.15 & $5.49(1.18)$ & $5.67(1.12)$ & -.18 \\
\hline Assurance & $5.85(.92)$ & $5.98(.87)$ & -.13 & $5.70(1.00)$ & $5.86(.98)$ & -.16 \\
\hline $\begin{array}{l}\text { Environmental } \\
\text { impact }\end{array}$ & $5.92(1.08)$ & $6.00(1.08)$ & -.08 & $5.77(1.18)$ & $5.91(1.12)$ & -.14 \\
\hline Recycling ratio & 6.09 (.99) & $6.08(1.02)$ & .01 & $5.81(1.10)$ & $5.93(1.11)$ & -.12 \\
\hline $\begin{array}{l}\text { Energy conser- } \\
\text { vation }\end{array}$ & $5.52(1.21)$ & $5.78(1.14)$ & $-.26^{*}$ & $5.43(1.26)$ & $5.67(1.18)$ & $-.24^{*}$ \\
\hline $\begin{array}{c}\text { Recycling } \\
\text { packing } \\
\text { material }\end{array}$ & $5.89(1.09)$ & $6.05(1.03)$ & -.16 & $5.78(1.15)$ & $5.91(1.11)$ & -.13 \\
\hline Reliability & $5.50(1.14)$ & $5.71(1.12)$ & -.21 & $5.37(1.18)$ & $5.51(1.20)$ & -.14 \\
\hline $\begin{array}{l}\text { Functional } \\
\text { performance }\end{array}$ & $5.49(1.26)$ & $5.72(1.22)$ & -.23 & $5.29(1.34)$ & $5.51(1.28)$ & -.22 \\
\hline Conformance & $5.63(1.08)$ & $5.81(1.13)$ & -.18 & $5.54(1.13)$ & $5.62(1.20)$ & -.08 \\
\hline Durability & $5.37(1.40)$ & $5.58(1.33)$ & -.21 & $5.27(1.44)$ & $5.38(1.41)$ & -.11 \\
\hline
\end{tabular}

G1 non-green product users, $G 2$ green product users, $S D$ standard deviation ${ }^{*} p<.05$ 
$(p<.05)$ between the two groups for both expectation and perception. This result can be explained as green product users, more than non-green consumers, believe that conserving energy during green sportswear production processes can lead to a reduction in energy consumption in general. This additional analysis did illuminate a great deal in explaining the non-supported hypotheses as well as providing some insights for future research.

In addition, based on consumers' experiences within both groups, the main reasons for non-green product users to be unwilling to purchase green sportswear and/or green products were related to premium price (31.1\%) followed by limited product availability (24.6\%) and lack of product information (21.3\%). On the other hand, the key reasons for green product users to be unwilling to purchase green sportswear and green products were more connected with a lack of product information (44.9\%) followed by limited product availability (25.1\%) and premium price (13.9\%). In spite of apparel companies' continuous efforts to incorporate sustainability practices in their product development processes and their strategic promotion of this movement via social media, both consumer groups in this study still feel like they lack product information about sustainable (or green) sportswear and think there are limited products available in green sportswear.

\section{Conclusion and future implications}

The findings of this study suggest that creating a positive attitude toward buying green sportswear enables a significant consideration for apparel retailers who aim to increase consumers' purchase intention for green sportswear. As a result, this study suggests for apparel retailers to develop effective and different segment marketing strategies between non-green and green product users that meet consumers' satisfaction and awareness for green sportswear. Numerous studies have been conducted to examine the effects of green products on consumers' purchase intention within diverse disciplines; however, limited research has investigated on the effects of consumers' expectation and perception on purchasing intention for green sportswear. Therefore, this study is unique in terms of proposing and testing an extended conceptual model by integrating antecedent variables (expectation and perception) with the concepts of the theory of planned behavior (subjective norm, perceived behavior control, attitude, and purchase intention). SEM analysis was performed to examine an overall path model using a whole sample of study participants and a comparative model using the two different consumer groups from the sample.

The results confirmed that significant effects of expectation, perception, subjective norm, and attitude as a mediator variable, played important roles in purchasing green sportswear in the overall conception model; however, different from our original hypothesis, perceived behavior control $(\mathrm{PBC})$ did not have any effect on attitude and purchase intention for green sportswear. In the comparative model testing, significant differences were found in the two groups in direct relation to both expectation and $\mathrm{PBC}$ towards purchase intention for green sportswear. Furthermore, moderating effect of attitude on the relationship between perception and purchase intention was significantly different between the two groups due to positive prior purchasing experience of green product users. Therefore, expectation, subjective norm, and attitude emerged as important factors in the comparative model. 
More specifically, when comparing the two consumer groups, a significant difference was found in an energy conservation item under the assurance sub-dimension for both expectation and perception. Interestingly, non-green product users were unwilling to purchase green sportswear due to the premium price, while green product users were unwilling to purchase green sportswear due to a lack of information about green products. From the findings, we can conclude that consumers' previous purchase experiences with green products facilitate their purchase intention for green sportswear.

The modified version of the theory of planned behavior, adding two additional variables (expectation and perception), was demonstrated to be effective for testing consumers' purchase intention for green sportswear. This model can be a useful tool for examining consumers' purchase intention for other types of green products available on the market. Future research should retest this model with other product categories and consider adding other variables (e.g., satisfaction) closely related to perception and expectation to test the effectiveness of this modified model.

The findings of this study provide insights for practical implications considering the following variables: expectation, perception, and subjective norm. Consumer experience campaigns regarding environmental concerns and products can lead to greatly increasing consumers' awareness about green sportswear and its consumption. Sale's managers should make effort on educating consumers' direct and indirect benefits about the environmental preservation, energy conservation, and human well-being through social media and prior experience campaign. They can also use celebrity effects to conduct green-related campaign to form consumers' favorable attitude towards green sportswear consumption. Therefore, increasing the level of subjective norm as well as attitude, thereby increasing the likelihood of purchasing green sportswear, it is important to enhance consumers' expectation by applying green cause-related marketing in advertising and promotional activities.

Furthermore, given the important mediating effect of attitude, expectation, perception, and subjective norm in predicting consumers' behavioral intention towards purchasing green sportswear, apparel retailers may consider providing all relevant information about green products upfront so that consumers' awareness of the green sportswear can be eventually improved. What is more, it is vital to convince consumers that they can make a substantial difference in the environment by using green products.

Although an online survey using MTurk provided a sample from diverse U.S. geographical locations, the sampling pool was limited to only those individuals who had access to MTurk. It is recommended that future researchers conduct a similar study with a U.S. representative sampling frame to obtain more comprehensive data. The small or uneven sample size between two consumer groups may be problematic for the SEM analysis. For future research, we recommend having an even number of sample size of more than 220 for each group (Hair et al. 2009). Although the quantitative approach allowed examination of the influence of key factors on consumers' purchase intention for green sportswear, it was unable to fully provide the underlying reasons to the phenomenon. In this regard, a qualitative research approach is useful for exploring more detailed reasons underlying the relationships among variables and green sportswear purchasing behavior through different consumer characteristics. 


\section{Authors' contributions}

$\mathrm{CN}$ and $\mathrm{YL}$ originated the research idea. $\mathrm{CN}, \mathrm{HD}$, and $\mathrm{YL}$ designed and conducted the research. $\mathrm{CN}$ and $\mathrm{HD}$ collected and analyzed the data and drafted the manuscript. CN and HD drafted literature review. YL supervised research design and conduction, revised and improved the manuscript. CN and YL contributed on the improvement and revision of the manuscript. All authors read and approved the final manuscript.

\section{Competing interests}

The authors declare that they have no competing interests.

Received: 16 June 2016 Accepted: 1 November 2016

Published online: 17 January 2017

\section{References}

Ajzen, I. (1991). The theory of planned behavior. Organizational Behavior and Human Decision Processes, 50(2), 179-211.

Ajzen, I. (2002). Perceived behavioral control, self-efficacy, locus of control, and the theory of planned behavior. Journal of Applied Social Psychology, 32(4), 665-683.

Ajzen, I., \& Fishbein, M. (1980). Understanding attitudes and predicting social behaviour. Upper Saddle River: Prentice-Hall.

Ajzen, I., \& Madden, T. J. (1986). Prediction of goal-directed behavior: attitudes, intentions, and perceived behavioral control. Journal of Experimental Social Psychology, 22(5), 453-474.

Anderson, E. W., \& Fornell, C. (2000). Foundations of the American customer satisfaction index. Total Quality Management, $11(7), 869-882$.

Armitage, C. J., \& Talibudeen, L. (2010). Test of a brief theory of planned behaviour-based intervention to promote adolescent safe sex intentions. British Journal of Psychology, 101(1), 155-172.

Barber, N. A., Bishop, M., \& Gruen, T. (2014). Who pays more (or less) for pro-environmental consumer goods? Using the auction method to assess actual willingness-to-pay. Journal of Environmental Psychology, 40, 218-227.

Boulding, W., Kalra, A., Staelin, R., \& Zeithaml, V. A. (1993). A dynamic process model of service quality: from expectations to behavioral intentions. Journal of Marketing Research, 30(1), 7-27.

Chang, M. K. (1998). Predicting unethical behavior: a comparison of the theory of reasoned action and the theory of planned behavior. Journal of Business Ethics, 17(16), 1825-1834.

Chen, T. B., \& Chai, L. T. (2010). Attitude towards the environment and green products: consumers' perspective. Management Science and Engineering, 4(2), 27-39.

Coleman, L. J., Bahnan, N., Kelkar, M., \& Curry, N. (2011). Walking the walk: how the theory of reasoned action explains adult and student intentions to go green. Journal of Applied Business Research, 27(3), 107-116.

Cowan, K., \& Kinley, T. (2014). Green spirit: consumer empathies for green apparel. International Journal of Consumer Studies, 38(5), 493-499.

Creyer, E. H., \& Ross, W. T., Jr. (1997). Tradeoffs between price and quality: how a value index affects preference formation. The Journal of Consumer Affairs, 31(2), 280-302.

Diddi, S., \& Niehm, L. S. (2016). Corporate social responsibility in the retail apparel context: exploring consumers' personal and normative influences on patronage intentions. Journal of Marketing Channels, 23(1-2), 60-76.

Fitzmaurice, J. (2005). Incorporating consumers' motivations into the theory of reasoned action. Psychology \& Marketing, 22(11), 911-929.

Goodman, J. K., Cryder, C. E., \& Cheema, A. (2013). Data collection in a flat world: the strengths and weaknesses of mechanical turk samples. Journal of Behavioral Decision Making, 26(13), 213-224.

Gopi, M., \& Ramayah, T. (2007). Applicability of theory of planned behavior in predicting intention to trade online: some evidence from a developing country. International Journal of Emerging Markets, 2(4), 348-360.

Hair, J. F., Black, W. C., Babin, B. J., Anderson, R. E., \& Tatham, R. L. (2009). Multivariate Data Analysis (7th ed.). Upper Saddle River: Pearson Prentice Hall.

Han, T. I., \& Chung, J. E. (2014). Korean consumers' motivations and perceived risks toward the purchase of organic cotton apparel. Clothing and Textiles Research Journal, 32(4), 235-250.

Hast, A., Syri, S., Jokiniemi, J., Huuskonen, M., \& Cross, S. (2015). Review of green electricity products in the United Kingdom, Germany and Finland. Renewable and Sustainable Energy Reviews, 42, 1370-1384.

Hur, W. M., Yoo, J. J., \& Hur, J. (2015). Exploring the relationship between green consumption value, satisfaction, and loyalty to hybrid car in elderly consumers. Human Factors and Ergonomics in Manufacturing \& Service Industries, 25(4), 398-408.

Joergens, C. (2006). Current research development ethical fashion: myth or future trend? Journal of Fashion Marketing and Management, 10(3), 360-371.

Johe, M. H., \& Bhullar, N. (2016). To buy or not to buy: the roles of self-identity, attitudes, perceived behavioral control, and norms in organic consumerism. Ecological Economics, 128, 99-105.

Kang, J., Liu, C., \& Kim, S. H. (2013). Environmentally sustainable textile and apparel consumption: the role of consumer knowledge, perceived consumer effectiveness and perceived personal relevance. International Journal of Consumer Studies, 37(4), 442-452.

Kaye, L. (2011). Clothing industry giants launch sustainable apparel coalition. http://www.triplepundit.com/2011/03/ sustainable-apparel-coalition/

Kilbourne, W., \& Pickett, G. (2008). How materialism affects environmental beliefs, concern, and environmentally responsible behavior. Journal of Business Research, 61(9), 885-893.

Kim, Y. H., \& Chung, J. E. (2011). Consumer purchase intention for organic personal care products. Journal of Consumer Marketing, 28(1), 40-47. 
Kim, H., \& Karpova, E. (2010). Consumer attitudes toward fashion counterfeits: application of the theory of planned behavior. Clothing and Textiles Research Journal, 28(2), 79-94.

Ko, S. B. (2012). Predictors of purchase intention toward green apparel products in the US and China (Unpublished doctoral dissertation). Stillwater: Oklahoma State University.

Kotler, P., \& Keller, K. L. (2006). Marketing management (12th ed.). Upper Saddle River: Pearson Prentice Hall Inc.

Lai, C. K., \& Cheng, E. W. (2016). Green purchase behavior of undergraduate students in Hong Kong. The Social Science Journal, 53, 67-76.

Laroche, M., Bergeron, J., \& Barbaro-Forleo, G. (2001). Targeting consumers who are willing to pay more for environmentally friendly products. Journal of Consumer Marketing, 18(6), 503-520.

Lee, N., Choi, Y. J., Youn, C., \& Lee, Y. (2012). Does green fashion retailing make consumers more eco-friendly? The influence of green fashion products and campaigns on green consciousness and behavior. Clothing and Textiles Research Journal, 30(1), 67-82.

Lee, C. K., Lee, Y. C., Chuang, Y. S., \& Wu, W. L. (2014). The Effect of electronic word-of mouth, customer expectations, and emotions on intention to take low cost airlines Advanced Approaches to Intelligent Information and Database Systems (pp. 69-75). New York: Springer International Publishing.

Liobikienè, G., Mandravickaitè, J., \& Bernatonienè, J. (2016). Theory of planned behavior approach to understand the green purchasing behavior in the EU: a cross-cultural study. Ecological Economics, 125(5), 38-46.

Lockwood, L. (2012, September 8). Sportswear: An American invention. http://wwd.com/globe-news/ ready-to-wear-sportswear/sportswear-an-american-invention-6241103/.

Madden, T. J., Ellen, P. S., \& Ajzen, I. (1992). A comparison of the theory of planned behavior and the theory of reasoned action. Personality and Social Psychology Bulletin, 18(1), 3-9.

Mandese, J. (1991). New study finds green confusion. Advertising Age, 62(45), 1-56.

Mintel. (2014). Fitness clothing-US-October 2014. http://store.mintel.com/fitness-clothing-us-October-2014.

Moser, A. K. (2015). Thinking green, buying green? Drivers of pro-environmental purchasing behavior. Journal of Consumer Marketing, 32(3), 167-175.

Noble, S. M., Haytko, D. L., \& Phillips, J. (2009). What drives college-age generation Y consumers? Journal of Business Research, 62(2), 617-628.

Nunnally, J., \& Bernstein, I. (1994). Psychometric Theory. New York: McGraw-Hill.

Oliver, R. L. (1981). Measurement and evaluation of satisfaction processes in retail settings. Journal of Retailing, 57(3), $25-48$.

Parasuraman, A., Zeithaml, V. A., \& Berry, L. L. (1985). A conceptual model of service quality and its implications for future research. The Journal of Marketing, 49(4), 41-50.

Pasquarelli, A. (2014). Workout clothes get tailored for work. http://www.crainsnewyork.com/article/20140925/RETAIL_ APPAREL/140929917/workout-clothes-get-tailored-for-work. Accessed 25 Sept 2014.

Paul, J., Modi, A., \& Patel, J. (2016). Predicting green product consumption using theory of planned behavior and reasoned action. Journal of Retailing and Consumer Services, 29, 123-134.

Rahbar, E., \& Wahid, A. N. (2011). Investigation of green marketing tools' effect on consumers' purchase behavior. Business Strategy Series, 12(2), 73-83.

Richins, M. L. (1983). Negative word-of-mouth by dissatisfied consumers: a pilot study. The Journal of Marketing, 47(1), 68-78.

Roberts, J. A. (1996). Green consumers in the 1990s: profile and implications for advertising. Journal of Business Research, $36(3), 217-231$

Sahni, $\mathrm{H}$ (2016). Towards sustainable fashion-Computer technology integration for a green fashion value-chain. http://www.fibre2fashion.com/industry-article/4574/ towards-sustainable-fashion-computer-technology-integration-for-a-green-fashion-value-chain?page $=1$.

Sherman, L. (2014). For the activewear market, there's no way but up. https://www.businessoffashion.com/articles/ intelligence/activewear-lululemon-nike-hm-sweaty-betty.

Smith, R. E., \& Swinyard, W. R. (1983). Attitude-behavior consistency: the impact of product trial versus advertising. Journal of Marketing Research, 20, 257-267.

Sobel, M. E. (1986). Some new results on indirect effects and their standard errors in covariance structure models. Sociological Methodology, 16, 159-186.

Sproles, G. B. (1979). Fashion: Consumer behavior toward dress. Minneapolis: Burgess Publishing Company.

Sustainable Apparel Coalition. (2014). Current members. http://www.apparelcoalition.org/current-members/.

Taylor, S., \& Todd, P. (1995). Decomposition and crossover effects in the theory of planned behavior: aA study of consumer adoption intentions. International Journal of Research in Marketing, 12(2), 137-155.

Tonglet, M., Phillips, P. S., \& Read, A. D. (2004). Using the theory of planned behaviour to investigate the determinants of recycling behaviour: a case study from Brixworth, UK. Resources, Conservation and Recycling, 41(3), 191-214.

Tseng, S.-C., \& Hung, S.-W. (2013). A framework identifying the gaps between customers' expectations and their perceptions in green products. Journal of Cleaner Production, 59, 174-184.

Tsiotsou, R. (2006). The role of perceived product quality and overall satisfaction on purchase intentions. International Journal of Consumer Studies, 30(2), 207-217.

Umberson, K. (2008). Environmentally-friendly purchase intentions: Debunking the misconception behind apathetic consumer attitudes (Unpublished doctoral dissertation). Texas: University of North Texas.

Vazifehdoust, H., Taleghani, M., Esmaeilpour, F., \& Nazari, K. (2013). Purchasing green to become greener: factors influence consumers' green purchasing behavior. Management Science Letters, 3(9), 2489-2500.

Xu, Y., Chen, Y., Burman, R., \& Zhao, H. (2014). Second-hand clothing consumption: a cross-cultural comparison between American and Chinese young consumers. International Journal of Consumer Studies, 38(6), 670-677.

Zheng, Y., \& Chi, T. (2015). Factors influencing purchase intention towards environmentally friendly apparel: an empirical study of US consumers. International Journal of Fashion Design, Technology and Education, 8(2), 68-77. 